\title{
Nonstarter Lactic Acid Bacteria Biofilms and Calcium Lactate Crystals in Cheddar Cheese
}

\author{
S. Agarwal, ${ }^{\star}$ K. Sharma,* B. G. Swanson, ${ }^{\star}$ G. Ü. Yüksel,† and S. Clark ${ }^{\star 1}$ \\ *Department of Food Science and Human Nutrition, Washington State University, Pullman 99164 \\ †Department of Food Science and Toxicology and Department of Microbiology, Molecular Biology, \\ and Biochemistry, University of Idaho, Moscow 83844
}

\section{ABSTRACT}

A sanitized cheese plant was swabbed for the presence of nonstarter lactic acid bacteria (NSLAB) biofilms. Swabs were analyzed to determine the sources and microorganisms responsible for contamination. In pilot plant experiments, cheese vats filled with standard cheese milk (lactose:protein $=1.47$ ) and ultrafiltered cheese milk (lactose:protein $=1.23$ ) were inoculated with Lactococcus lactis ssp. cremoris starter culture (8 $\log \mathrm{cfu} / \mathrm{mL})$ with or without Lactobacillus curvatus or Pediococci acidilactici as adjunct cultures (2 log cfu/mL). Cheddar cheeses were aged at 7.2 or $10^{\circ} \mathrm{C}$ for $168 \mathrm{~d}$. The raw milk silo, ultrafiltration unit, cheddaring belt, and cheese tower had NSLAB biofilms ranging from 2 to $4 \log \mathrm{cfu} / 100 \mathrm{~cm}^{2}$. The population of Lb. curvatus reached $8 \log \mathrm{cfu} / \mathrm{g}$, whereas $P$. acidilactici reached $7 \mathrm{log} \mathrm{cfu} / \mathrm{g}$ of experimental Cheddar cheese in $14 \mathrm{~d}$. Higher NSLAB counts were observed in the first $14 \mathrm{~d}$ of aging in cheese stored at $10^{\circ} \mathrm{C}$ compared with that stored at $7.2^{\circ} \mathrm{C}$. However, microbial counts decreased more quickly in Cheddar cheeses aged at $10^{\circ} \mathrm{C}$ compared with $7.2^{\circ} \mathrm{C}$ after $28 \mathrm{~d}$. In cheeses without specific adjunct cultures ( $L b$. curvatus or P. acidilactici), calcium lactate crystals were not observed within $168 \mathrm{~d}$. However, crystals were observed after only 56 $\mathrm{d}$ in cheeses containing $L b$. curvatus, which also had increased concentration of $\mathrm{D}(-)$-lactic acid compared with control cheeses. Our research shows that low levels of contamination with certain NSLAB can result in calcium lactate crystals, regardless of lactose:protein ratio. Key words: nonstarter lactic acid bacteria, calcium lactate crystal, biofilm, Lactobacillus curvatus

\section{INTRODUCTION}

Nearly a century after their first description (Van Slyke and Publow, 1909), occurrence of white crystals on the surface of Cheddar cheese continues to trouble

Received April 11, 2005.

Accepted November 22, 2005.

${ }^{1}$ Corresponding author: stephclark@wsu.edu cheese manufacturers (Chou et al., 2003; Agarwal et al., 2005; Blake et al., 2005). McDowall and McDowell (1939) identified the crystals isolated from Cheddar cheese as calcium lactate. The appearance of white haze on Cheddar cheese, identified as calcium lactate crystals (CLC), has been reported by numerous researchers (Harper et al., 1953; Dybing et al., 1988; Chou et al., 2003). Most of the white haze appearing on cheeses aged 2 to $8 \mathrm{mo}$ is identified as CLC (Johnson et al., 1990a,b; Chou et al., 2003). White crystals render cheese unappealing to consumers, because consumers perceive cheeses with CLC as infested with mold or having serious manufacturing defects. Vendors and consumers complain to manufacturing plants about the white haze of crystals appearing on surfaces of both vacuum-packaged and gas-flushed cheeses. Cheese manufacturers endure millions of dollars in lost sales and revenue when CLC appear on cheese surfaces during aging and on store shelves (Johnson, 2004; Swearingen, 2004a).

Calcium lactate crystals on cheese are attributed to complex interactions among cheese milk composition, cheese-making procedures, cheese microflora, packaging, and aging temperatures. Nonstarter lactic acid bacteria (NSLAB) and fluctuating storage temperatures result in increased development of CLC on cheese (Somers et al., 2001; Chou et al., 2003). Nonstarter lactic acid bacteria exhibit a remarkable ability to grow in cheese during aging from low initial numbers of (2 to $3 \log \mathrm{cfu} / \mathrm{g}$ ) to high numbers (8 log cfu/g), and dominate the microbial population in cheese within the first few months of aging (Khalid and Marth, 1990; Williams et al., 2000). The lactate present in CLC is often identified as a racemic mixture of $\mathrm{D}(-)$ and $\mathrm{L}(+)$ forms (Dybing et al., 1988; Johnson et al., 1990b; Chou et al., 2003). D(-)Lactate is less soluble than the $\mathrm{L}(+)$ form of lactate (Cao et al., 2001). Some NSLAB that racemize L(+)-lactate to D(-)-lactate (Turner and Thomas, 1980; Johnson et al., 1990b; Chou et al., 2003) contribute to increased CLC in cheese. Adding to development of lactate crystals is the fact that NSLAB also form biofilms that are difficult to remove from equipment surfaces and may lead to contamination of cheeses (Somers et al., 2001). 
A common practice that may lead to development of CLC is standardization of cheese milk. Many commercial cheese plants concentrate cheese milk to increase cheese yield (Kosikowski and Mistry, 1997). Manufacturers may increase the total solids of cheese milk by adding milk powder, evaporated milk, or concentrated milk using membrane filtration (reverse osmosis and UF). When additional milk solids are added to cheese milk, lactose concentration is also increased, which may exacerbate development of CLC. When Chou et al. (2003) made cheese with milk containing $L b$. curvatus, $5.2 \%$ lactose, and a protein to fat ratio of 0.84 , CLC appeared on cheese surfaces after only $35 \mathrm{~d}$. Chou et al. (2003) concluded that certain NSLAB were responsible for CLC in Cheddar cheese.

High aging temperatures are sometimes used by cheese manufacturers to accelerate cheese ripening (Shakeel-Ur-Rehman et al., 2000). High aging temperatures are generally associated with increased growth of NSLAB, rapid conversion of lactose to lactic acid, and an increased potential for CLC formation. Chou et al. (2003) reported increased crystal presence in cheeses aged at $13^{\circ} \mathrm{C}$ followed by aging at $4^{\circ} \mathrm{C}$ than in cheeses aged at only at 4 or $13^{\circ} \mathrm{C}$, or aged at $4^{\circ} \mathrm{C}$ followed by aging at $13^{\circ} \mathrm{C}$.

Ultrafiltration is an alternative to increase total solids without increasing the final lactose concentration in cheese milk. The current study was designed to determine whether the use of UF, while maintaining the standard level of lactose in cheese milk contaminated with NSLAB, would limit CLC. Additionally, objectives were to determine locations in a cheese plant that can be sources of NSLAB and to evaluate the ability of NSLAB to survive and grow in cheese during aging. Our goal was to study the complex relationships among cheese milk composition, NSLAB, and aging conditions on CLC formation on cheese.

\section{MATERIALS AND METHODS}

\section{Plant Visit}

A Washington State commercial cheese manufacturing plant was visited in November 2001. Wet swab samples (duplicate swabs from each location, 3M Quick Swabs, 3M Microbiology Products, St. Paul, MN) were taken from cleaned, sanitized, and dry equipment surfaces that were commonly in direct contact with milk and cheese curd throughout the manufacturing process. Before the start of production for that particular day, the cheese plant was cleaned and sanitized using alkaline chlorinated detergents, followed by a rinse with a sodium hypochlorite solution using the installed clean in-place system. The equipment surfaces were swabbed according to manufacturer's instructions $\left(100 \mathrm{~cm}^{2}\right.$ area $)$ after cleaning and sanitizing to check for the presence of biofilms. With the goal of quantifying NSLAB proliferation from the equipment surfaces throughout the cheese-making process, dry swab samples were taken from equipment surfaces $\left(100 \mathrm{~cm}^{2}\right.$ area) that were in contact with cheese curd during a 5-h cheese-making process. For example, dry swabs samples were taken from the moist cheddaring belt that was in contact with cheese curd to study the growth of NSLAB at the beginning, middle, and end of the processing day. Swab samples were plated on 3M Petrifilm aerobic plate count plates (3M Microbiology) and on Lactobacillus MRS agar (Becton Dickinson and Co., Sparks, MD) plates and incubated at $32^{\circ} \mathrm{C}$ for $48 \mathrm{~h}$ under anaerobic conditions.

Raw materials, pasteurized milk, UF concentrated milk, cheese curd, whey, and finished cheese were analyzed for total aerobic plate count, total anaerobic count, and NSLAB count. Ultrafiltration was carried out on raw whole milk, fed into the UF unit, and maintained below $7.2^{\circ} \mathrm{C}$. Milk or cream was serially diluted using a $99-\mathrm{mL}$ dilution scheme and $0.2 \%$ peptone (Bacto Peptone, Becton Dickinson and Co.), pour plated on Lactobacillus MRS agar plates and 3M Petrifilm aerobic count plates, and the plates were incubated under aerobic conditions. To obtain total anaerobic counts, similarly plated samples were incubated in anaerobic jars (BBL GasPak 150 Systems, Becton Dickinson and Co.) under a $\mathrm{CO}_{2}$-enriched environment (BBL GasPak Plus Anaerobic System Envelopes with Palladium Catalyst, Becton Dickinson and Co.).

The wet swab samples, dry swab samples, and milk or cheese curd were taken from the raw milk silo, lines before and after the UF unit, a cream tank, balance tank, milk pasteurizer, cheese vats, Cheddarmaster, milling and salting machine, lines to cheese towers, and cheese towers. In large automated cheese plants, timing of the cheese-making process is synchronized and automated such that a single vat of milk can be followed from culturing through cheddaring, pressing, and aging. During the plant visit, 3 different single vats of milk/cheese were followed and sampled at selected unit operations throughout the manufacturing process to track microbial changes in milk from single vats over time. The sampling sequence was selected to study the buildup of NSLAB populations in cheese curd and on equipment surfaces. Cheese curds from the 3 different vats of milk were removed during the subsequent steps of cheese manufacturing until the cheese from the vats was packaged for aging.

For enumeration, $11 \mathrm{~g}$ of cheese curd was blended aseptically with $99 \mathrm{~mL}$ of $2 \%$ sodium citrate solution at $45^{\circ} \mathrm{C}$ for $2 \mathrm{~min}$ in stomacher bags (Stomacher 400 Strainer Bags, Seward Laboratory, London, UK) using 
a Stomacher (Lab Blender 400, model no. BA6021, Seward Laboratory). Serial dilutions were made from the cheese suspension with $99 \mathrm{~mL}$ of $0.2 \%$ peptone, and pour plated on Lactobacillus MRS agar plates and aerobic count plates. The inoculated MRS agar plates and aerobic count plates were incubated in an anaerobic jar (BBL GasPak 150 Systems, Becton Dickinson and Co.) under a $\mathrm{CO}_{2}$-enriched environment (BBL GasPak Plus Anaerobic Systems Envelops with Palladium Catalyst, Becton Dickinson and Co.) at $32^{\circ} \mathrm{C}$ for $48 \mathrm{~h}$. A second set of aerobic count plates were incubated at $32^{\circ} \mathrm{C}$ under aerobic conditions. To enumerate NSLAB in cheese ingredients, samples of cheese color $(1 \mathrm{~mL})$, rennet (1 $\mathrm{mL}$ ), and $1 \mathrm{~mL}$ of $10 \%$ salt solution were plated on Lactobacillus MRS agar plates and aerobic count plates and the plates were incubated under appropriate conditions.

\section{Sources of Adjunct Microorganisms}

Nonstarter lactic acid bacteria isolated from equipment surfaces and cheese curd were identified by observing growth on selected carbon sources in 96-well microplates (Biolog MT1, Microlog Systems, Hayward, $\mathrm{CA}$ ), in accordance with the instructions from the manufacturer. Nonstarter lactic acid bacteria were identified based on carbohydrate fermentation patterns (Chou et al., 2003), and were tested for the capability of racemizing $\mathrm{L}(+)$-lactic acid. Bacteria that racemize $\mathrm{L}(+)$ - to $\mathrm{D}(-)$-lactic acid are implicated in development of CLC (Thomas and Crow, 1983). Pediococcus acidilactici was isolated and selected for cheese manufacture experiments because of its efficient racemization of $L(+)$ - to $\mathrm{D}(-)$-lactate, and because it was isolated from milk and cheese samples obtained from the commercial cheese plant. Lactobacillus curvatus was previously isolated from aged cheese exhibiting crystals and identified by Chou et al. (2003).

\section{Cheese Manufacture}

Two batches of milk, standardized based on selected cheese-milk formulations used in industry, were selected to make cheeses in the Washington State University (WSU) Creamery pilot plant. Cheeses were manufactured in duplicate, with each replicate made from $90.8 \mathrm{~kg}$ of milk. Standard milk comprised $3.26 \%$ protein, $3.62 \%$ fat, and $12.13 \%$ total solids (lactose:protein = 1.47 , protein $:$ fat $=0.90$, lactose $=4.8 \%$ ). Three duplicate batches of cheese were made from standard milk: standard milk plus starter culture (batch 1), standard milk plus starter culture plus $P$. acidilactici adjunct culture (batch 2), and standard milk plus starter culture plus Lb. curvatus adjunct culture (batch 3 ). Three duplicate batches of cheese were made from UF milk (Blake et al., 2005), composed of $3.87 \%$ protein, $4.60 \%$ fat, and $13.81 \%$ total solids (lactose: protein $=1.23$, protein: fat $=$ 0.84 , lactose $=4.8 \%$ ): UF milk plus starter culture (batch 4), UF milk plus starter culture plus $P$. acidilactici adjunct culture (batch 5), and UF milk plus starter culture plus $L b$. curvatus adjunct culture (batch 6 ).

Starter culture, Lc. lactis ssp. cremoris \#98 (Chr. Hansen's Inc., Milwaukee, WI), was grown to a cell density of $8 \mathrm{log} \mathrm{cfu} / \mathrm{mL}$ of media with internal $\mathrm{pH}$-controlled buffer media (Vivolac, Indianapolis, IN) and inoculated into standardized milk at a rate of $1 \%(\mathrm{wt} / \mathrm{wt})$ at $32^{\circ} \mathrm{C}$. Pediococcus acidilactici and Lb. curvatus were grown to cell densities of $8 \log \mathrm{cfu} / \mathrm{mL}$ in Lactobacillus MRS broth (Becton Dickinson and Co.) and added to milk to achieve initial populations of 500 to $700 \mathrm{cfu} / \mathrm{mL}$ in the cheese milk to mimic the low initial NSLAB counts typically observed in pasteurized cheese milk (Johnson et al., 1990b).

Cheeses were made using standard procedures followed at the WSU Creamery. When the titratable acidity (\% of lactic acid) of the whey reached $0.45 \%$, the loaves were milled and curds were salted $(0.3 \% \mathrm{wt} / \mathrm{wt}$ of milk). After overnight pressing at $2.8 \mathrm{~kg} / \mathrm{cm}^{2}$, cheeses were cut into 150 -g pieces $(10 \times 4 \times 5 \mathrm{~cm})$ and vacuum packaged (model X180, Koch Supplies Inc., Kansas City, MO) in $15 \times 20 \mathrm{~cm}$, 3-mil high barrier Nylon/ ethyl vinyl alcohol/polyethylene vacuum pouches (Koch Supplies Inc.). Finished cheeses were then aged at either 7.2 or $10^{\circ} \mathrm{C}$. The $10^{\circ} \mathrm{C}$ temperature was selected as a temperature for accelerated ripening of Cheddar cheese (Law et al., 1979).

\section{Cheese Microbiology}

Four selective media were used to enumerate and identify the microbial populations in milk and cheese (Marshall, 1992). Cheese milk, cheese curd before pressing, and cheese curd after pressing were analyzed on $\mathrm{d} 7,14,28,56,84,112,140$, and 168. Each cheese was aseptically sampled, emulsified in $2 \%$ (wt/vol) trisodium citrate buffer $(\mathrm{pH} 8.75)$ maintained at $45^{\circ} \mathrm{C}$, diluted with $0.2 \%$ (wt/vol) peptone, and plated on 4 sets of Petri dishes. LM17 agar plates were selected to determine total counts (starter culture and NSLAB in $\mathrm{cfu} / \mathrm{g}$ ) and were incubated at $32^{\circ} \mathrm{C}$ for $48 \mathrm{~h}$. LM17 agar plates with added salt (4\%) were used for enumeration of $P$. acidilactici, and incubated at $32^{\circ} \mathrm{C}$ for $72 \mathrm{~h}$. Rogosa SL agar (Difco, Detroit, MI) plates, selective for enumeration of lactobacillus species, were used to enumerate potential environmental lactobacillus NSLAB contaminants, and were incubated at $32^{\circ} \mathrm{C}$ for $5 \mathrm{~d}$ under anaerobic conditions. Elliker agar (Difco) with 1,3,5 trichlorotetrazolium chloride $(5 \mu \mathrm{g} / \mathrm{mL})$ and Tween 80 (0.1\% wt/ 
vol), was used as a differential medium for distinguishing between starter culture (cocci) and NSLAB (rods) incubated at $32^{\circ} \mathrm{C}$ for $48 \mathrm{~h}$ (Marshall, 1992).

\section{Chemical Analysis}

Lactose, $\mathrm{L}(+)$ - and $\mathrm{D}(-)$-lactic acid concentrations in the experimental cheeses were determined $1 \mathrm{~d}$ after manufacture, and then at $7,14,56,84,112,140$, and $168 \mathrm{~d}$.

\section{Lactose Determination}

Three grams of grated cheese was blended with 70 $\mathrm{mL}$ of redistilled water (Millipore, $18 \Omega$ resistance) in stomacher bags (Stomacher 400 strainer bag, Seward Laboratory) for $5 \mathrm{~min}$. The mixture was transferred to a $100-\mathrm{mL}$ volumetric flask, and incubated for $15 \mathrm{~min}$ at $70^{\circ} \mathrm{C}$. After cooling to room temperature, $2 \mathrm{~mL}$ of 3 $M$ TCA was added and stirred. After $5 \mathrm{~min}$, the mixture was neutralized with $6 \mathrm{~mL}$ of $1 M \mathrm{NaOH}$. The volume was brought to $100 \mathrm{~mL}$ with redistilled water and the solution was placed at $7.2^{\circ} \mathrm{C}$ for $20 \mathrm{~min}$ to separate fat. The solution was filtered through Whatman filter paper \# 42. The filtrate was assayed for lactose using the manufacturer's method (lactose/D-galactose test combination, Boehringer Mannheim Co., Indianapolis, IN).

\section{Lactic Acid Determination}

Ten grams of grated cheese was added to $100 \mathrm{~mL}$ of $2 \%$ sodium citrate and the mixture was blended for 2 $\mathrm{min}$. The mixture was transferred to a $100-\mathrm{mL}$ volumetric flask and boiled for $5 \mathrm{~min}$ to dissolve the cheese. After cooling to room temperature, redistilled water was added to bring the volume to $100 \mathrm{~mL}$. Three milliliters of the cheese solution was mixed with $6 \mathrm{~mL}$ of $10 \%$ TCA. The mixture was placed in an ice bath for $5 \mathrm{~min}$ and filtered using Whatman filter paper \#42. The filtrate was assayed for $\mathrm{L}(+)$-lactic acid and $\mathrm{D}(-)$-lactic acid concentration using Boehringer Mannheim test kits [D(-)-lactic acid/L(+)-lactic acid test kits, Boehringer Mannheim Co.] and following the method in the insert. Data obtained were analyzed with LSD using SAS Proc GLM (SAS Institute, 1989). The $F$-statistics for ANOVA were computed using the SAS GLM procedure (SAS Institute, 1989).

\section{Crystal Identity}

Each 150 -g wedge of cheese $(10 \times 4 \times 5 \mathrm{~cm})$ was visually monitored for the presence of white crystals on the surfaces and on the package interior. Crystal identity was confirmed after initial observation. The cleaned crystals (Chou et al., 2003) were examined for x-ray diffraction pattern using a Siemens D 500 diffractometer (Siemens Co., New York, NY). Copper k $\alpha$ radiation at $30 \mathrm{~mA}$ and a diffraction pattern from the surface of molecules were collected from 5 to $60^{\circ}$ at a scan rate of $2 \theta / \mathrm{min}$, a step size of 0.05 , and counting time of $2 \mathrm{~s}$. The patterns were compared with identified crystals to confirm crystal identity.

\section{RESULTS AND DISCUSSION}

\section{Cheese Plant Visit}

Biofilms were detected on cleaned and sanitized equipment surfaces (Figure 1). Total anaerobic counts on Lactobacillus MRS agar plates, representing sanitized equipment surfaces, ranged from less than $1 \mathrm{log}$ to more than $3 \log / 100 \mathrm{~cm}^{2}$. High microbial counts obtained from the cleaned and sanitized UF unit (3.8 log $\mathrm{cfu} / 100 \mathrm{~cm}^{2}$ ) revealed the presence of biofilms as potential sources of future contamination. Total microbial counts from wet swab samples taken from 2 selected locations along pasteurized milk lines exhibited different bacterial counts. When the first location (line 1) was tested, no microorganism was detected. When the second location, (line 2) was tested, however, microorganisms (1.6 log cfu/100 $\mathrm{cm}^{2}$ ) were detected, suggesting that microbial populations can vary in numbers at different locations of the same equipment. The swab samples taken from the end of the cheddaring belt, the milling and salting machine, and lines to the cheese tower, and plated on Lactobacillus MRS agar plates had total anaerobic plate counts ranging from 1 to 2 $\log \mathrm{cfu} / 100 \mathrm{~cm}^{2}$ (Figure 1). Pediococcus acidilactici was isolated as the predominant microorganism from raw milk silo, UF unit, cheddaring belt, milling and salting machine, and line to cheese towers. All equipment surfaces that contained biofilms were in difficult-to-clean locations.

The total microbial count on equipment surfaces during cheese manufacturing increased over time (Figure 2 ). An increase is understandable because the cheesemaking environment is conducive to microbial growth. In Figure 2, the bars represent the counts obtained from equipment surfaces on aerobic count plates at different times during the cheese manufacturing process. After $1 \mathrm{~h}$, the Cheddarmaster location 1 exhibited a mean of $6.6 \log \mathrm{cfu} / 100 \mathrm{~cm}^{2}$ total plate count; after $5 \mathrm{~h}$, the counts from the same location increased to $7.5 \mathrm{log} \mathrm{cfu} /$ $100 \mathrm{~cm}^{2}$. The greatest increase in total microbial counts was in the lines to the cheese tower, where the microbial counts on surfaces increased from $5.3 \log \mathrm{cfu} / 100 \mathrm{~cm}^{2}$ in the first hour to $7.2 \log \mathrm{cfu} / 100 \mathrm{~cm}^{2}$ in the fifth hour. The findings are important because if NSLAB are present in the cheese-making environment, their popula- 


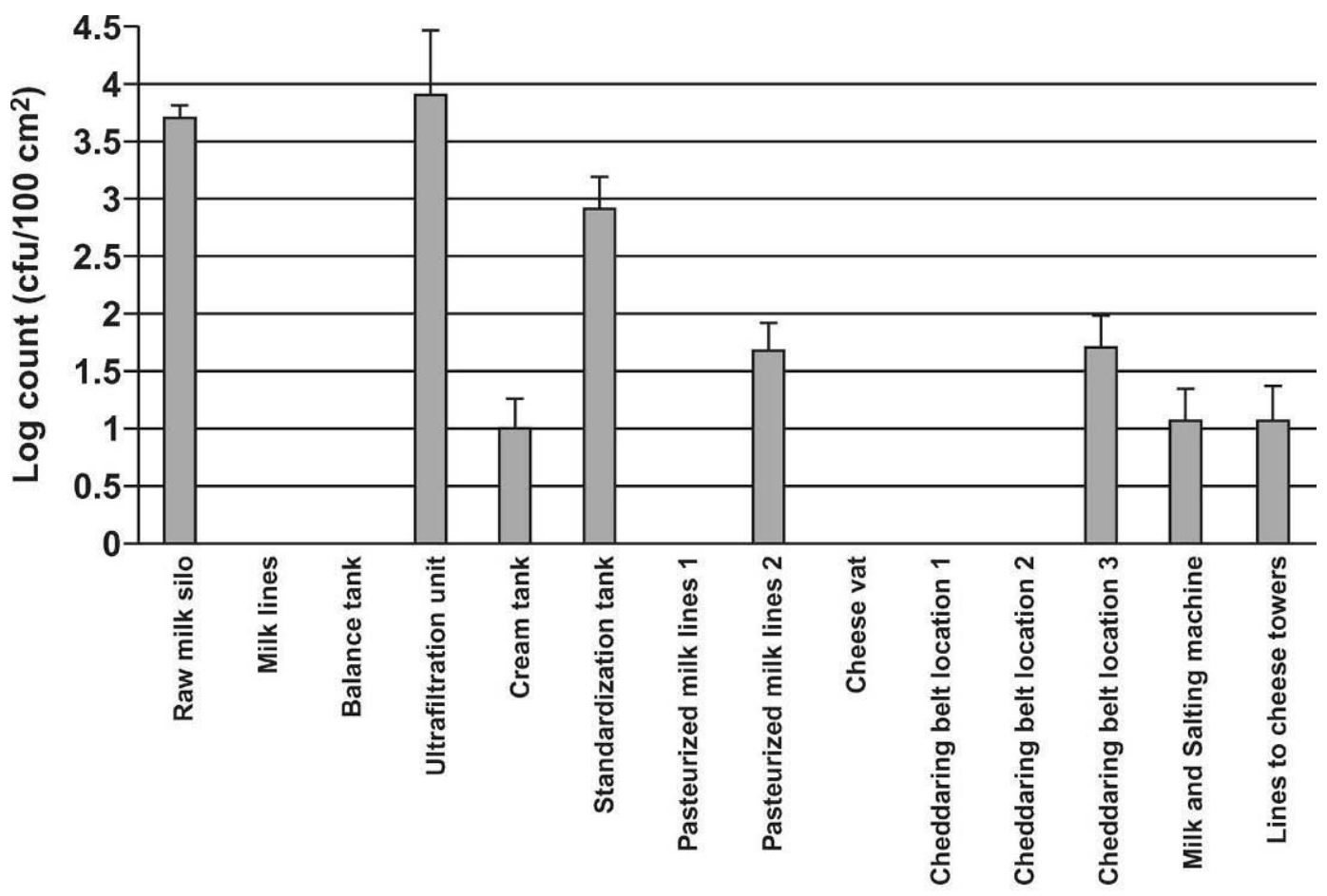

\section{Sanitized equipment surfaces}

Figure 1. Total microbial counts acquired from cleaned and sanitized equipment surfaces in a commercial cheese plant.

tions can increase rapidly during cheese manufacture. If not removed properly during cleaning or killed during sanitation, NSLAB biofilms represent potential sources of cheese contamination. It should be noted that there was a substantial decrease in microbial count on the milling and salting machine compared with microbial counts at Cheddarmaster location 3 , demonstrating that salt restricts the growth of microorganisms at the milling and salting machine location.

Microbial counts of milk, ingredients (chymosin, annatto, and salt), and cheese curd sampled throughout the manufacturing process are presented in Figure 3. After the UF of raw milk, there were sharp increases in Lactobacillus MRS agar plate counts (from 2.4 to 4.4 $\log \mathrm{cfu} / \mathrm{mL}$ ) and aerobic plate counts (from 4.2 to 8.0 $\log \mathrm{cfu} / \mathrm{mL}$ ). The increases in microbial counts indicate that microorganisms in raw milk were concentrated during UF, and psychrotrophic microorganisms might have multiplied during the 2 -h UF process. Cheese milk standardized by mixing whole milk, UF milk, and cream was pasteurized (Figure 3), destroying most of the microorganisms. However, the counts of 1 to $2 \log$ $\mathrm{cfu} / \mathrm{mL}$ for both anaerobic and aerobic bacteria after pasteurization demonstrate that some microorganisms survived milk pasteurization. Total microbial counts in cheese milk increased to $11 \log \mathrm{cfu} / \mathrm{mL}$ after addition of starter, whereas the NSLAB population remained at $2.0 \mathrm{log} \mathrm{cfu} / \mathrm{mL}$. The NSLAB population in whey hovered around 2.0 to $2.1 \log \mathrm{cfu} / \mathrm{mL}$ within the time curd was set, cut, cooked, and drained (Figure 3). Total (8.5 log $\mathrm{cfu} / \mathrm{g}$ ) and NSLAB (1.9 to $2.5 \mathrm{log} \mathrm{cfu} / \mathrm{g}$ ) counts were found in cheese curd during the cheddaring process. Importantly, NSLAB survived and reached a population of 3 to $3.5 \mathrm{log} \mathrm{cfu} / \mathrm{g}$ in cheese curd by the time of pressing. No microorganisms were recovered from chymosin, annatto, or salt, confirming that these additives were not a source of NSLAB. Because the additives were free of microbial contaminants, the main sources of NSLAB in cheese were equipment surfaces and the cheese-making environment. Equipment surfaces were swabbed for NSLAB, but neither the cheese plant walls, floors, vents, nor cheese-makers were swabbed.

\section{Results Regarding Experimental Cheese Trials}

Use of Adjunct Cultures. The total microbial counts in control cheeses increased from $6.8 \mathrm{log} \mathrm{cfu} / \mathrm{g}$ at the time of inoculation to $8.0 \mathrm{log} \mathrm{cfu} / \mathrm{g}$ soon after pressing, and then increased to between 8.0 and $8.3 \mathrm{log} \mathrm{cfu} / \mathrm{g}$ after $7 \mathrm{~d}$ of aging (Figures 4 and 5). The total counts in control cheeses then decreased rapidly after $14 \mathrm{~d}$. After $56 \mathrm{~d}$ of aging, significantly higher total counts 


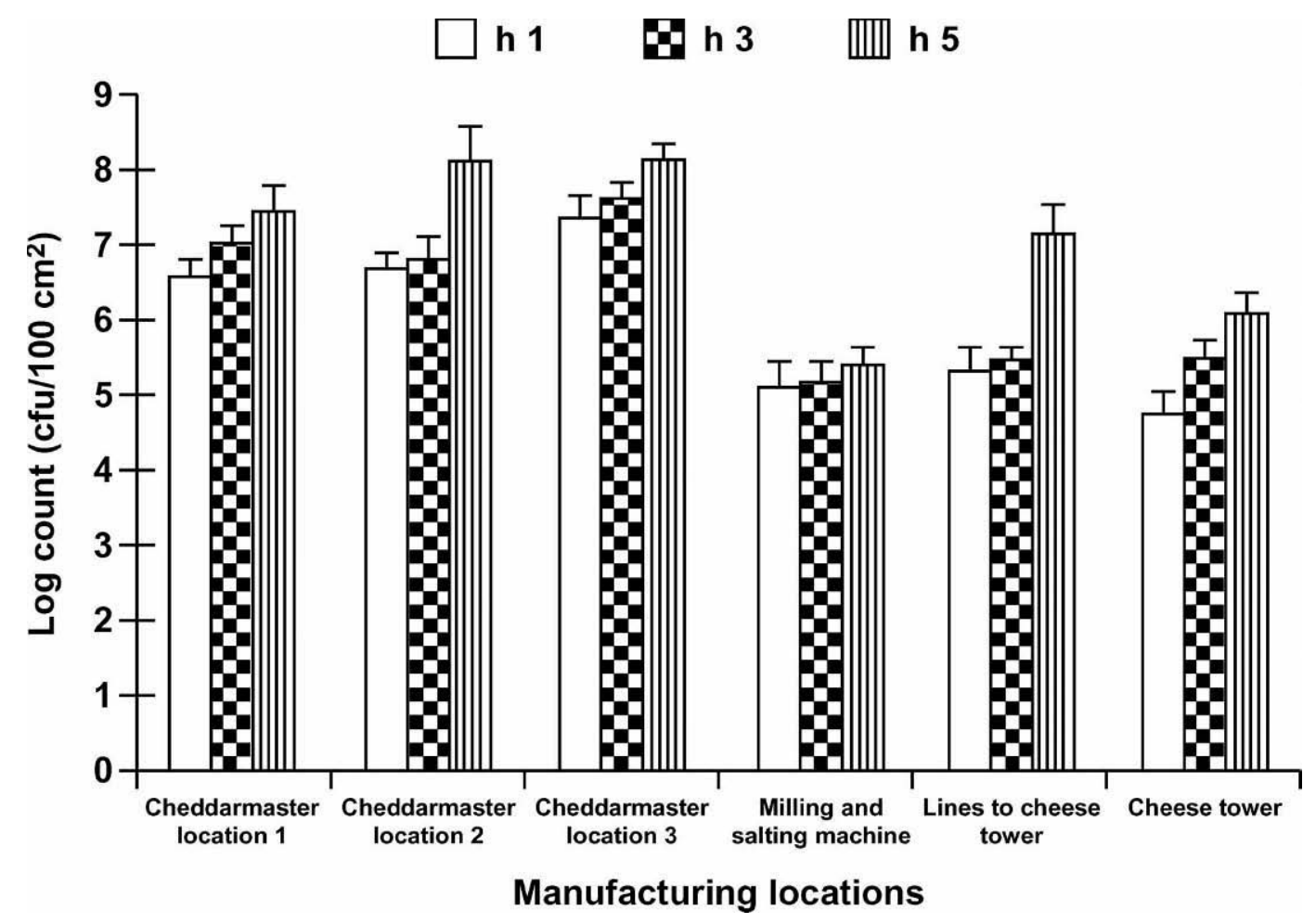

Figure 2. Change in total aerobic plate count on equipment surfaces during $5 \mathrm{~h}$ of processing time in a commercial cheese plant (mean of 3 cheese vats followed throughout processing).

were observed in cheeses inoculated with NSLAB $(6.5$ to $8.5 \mathrm{log} \mathrm{cfu} / \mathrm{g})$ adjuncts than in control (4.5 to 5.0 $\log \mathrm{cfu} / \mathrm{g}$ ) cheeses (Figures 4 and 5). Also, after 168 $\mathrm{d}$, standard control cheeses contained total counts of between 2.2 and $2.5 \log \mathrm{cfu} / \mathrm{g}$, whereas standard cheeses inoculated with adjuncts contained between 5.0 and 7.0 $\log \mathrm{cfu} / \mathrm{g}$ total counts (Figure 4), indicating that the starter bacteria died quickly during the aging process. Total counts in UF control cheese decreased to between 3.5 and $3.2 \mathrm{log} \mathrm{cfu} / \mathrm{g}$ after $168 \mathrm{~d}$ of aging (Figure 5). No colonies were observed on Rogosa SL agar of plated control cheeses or cheeses inoculated with adjunct $P$. acidilactici, indicating that no lactobacilli species were present in those cheeses. Aged cheeses without inoculated NSLAB typically exhibit lower microbial counts than inoculated cheeses (Thomas and Crow, 1983).

The total microbial counts in cheeses inoculated with $P$. acidilactici increased from $7.9 \mathrm{log} \mathrm{cfu} / \mathrm{g}$ after pressing to between 8.0 and $8.3 \mathrm{log}$ cfu/g after $7 \mathrm{~d}$ of aging (Figures 4 and 5). The total counts declined slowly after 28 $\mathrm{d}$ to reach 5.8 to $4.8 \mathrm{cfu} \mathrm{log} / \mathrm{g}$ after $168 \mathrm{~d}$ in standard cheese (Figure 4). Meanwhile, total counts in UF cheeses inoculated with $P$. acidilactici decreased to between 6.4 and $5.4 \mathrm{log} \mathrm{cfu} / \mathrm{g}$ after $168 \mathrm{~d}$ of aging (Figure 5 ). The population of $P$. acidilactici, specifically, increased rapidly in cheese curd even though the cheese milk was only inoculated at $2 \log \mathrm{cfu} / \mathrm{mL}$, and reached $7.0 \mathrm{log} \mathrm{cfu} / \mathrm{g}$ by the end of $14 \mathrm{~d}$ of aging. The NSLAB population in cheeses inoculated with $P$. acidilactici increased quickly during cheese manufacture and remained high (5.0 log cfu/g) throughout $168 \mathrm{~d}$ of aging (Figures 6 and 7). High NSLAB counts show that certain strains of $P$. acidilactici survive well and grow in Cheddar cheese during manufacture and aging.

The total microbial counts in cheeses inoculated with $L b$. curvatus increased from $6.8 \mathrm{log} \mathrm{cfu} / \mathrm{g}$ at the time of culturing to between 8.3 and $8.4 \mathrm{log} \mathrm{cfu} / \mathrm{g}$ when the cheese was removed from the press, and then increased to 8.6 to $8.9 \mathrm{log} \mathrm{cfu} / \mathrm{g}$ after $14 \mathrm{~d}$ of aging (Figures 4 and 5). The total microbial counts in standard cheese inoculated with $L b$. curvatus remained above $6.0 \mathrm{log}$ cfu/g (6.1 to $7.2 \log \mathrm{cfu} / \mathrm{g}$ ) after $168 \mathrm{~d}$ of aging; a larger population than control cheeses (2.3 to $2.5 \log \mathrm{cfu} / \mathrm{g}$ ) and cheeses with $P$. acidilactici ( 4.5 to $5.8 \mathrm{log} \mathrm{cfu} / \mathrm{g}$ ). Meanwhile, the total microbial counts in UF cheeses with $L b$. curvatus remained above $6.5 \mathrm{log} \mathrm{cfu} / \mathrm{g}$ and reached a higher final count than standard cheeses $(6.6$ to $7.8 \mathrm{log} \mathrm{cfu} / \mathrm{g}$ ) after $168 \mathrm{~d}$ of aging. A rapid increase in population of $L b$. curvatus to $8.5 \mathrm{log} \mathrm{cfu} / \mathrm{g}$ was observed in experimental cheeses (standard and UF) during the first $14 \mathrm{~d}$ of ripening, even though the inoculation concentration was $2.5 \log \mathrm{cfu} / \mathrm{g}$ (Figures 6 and 7). 


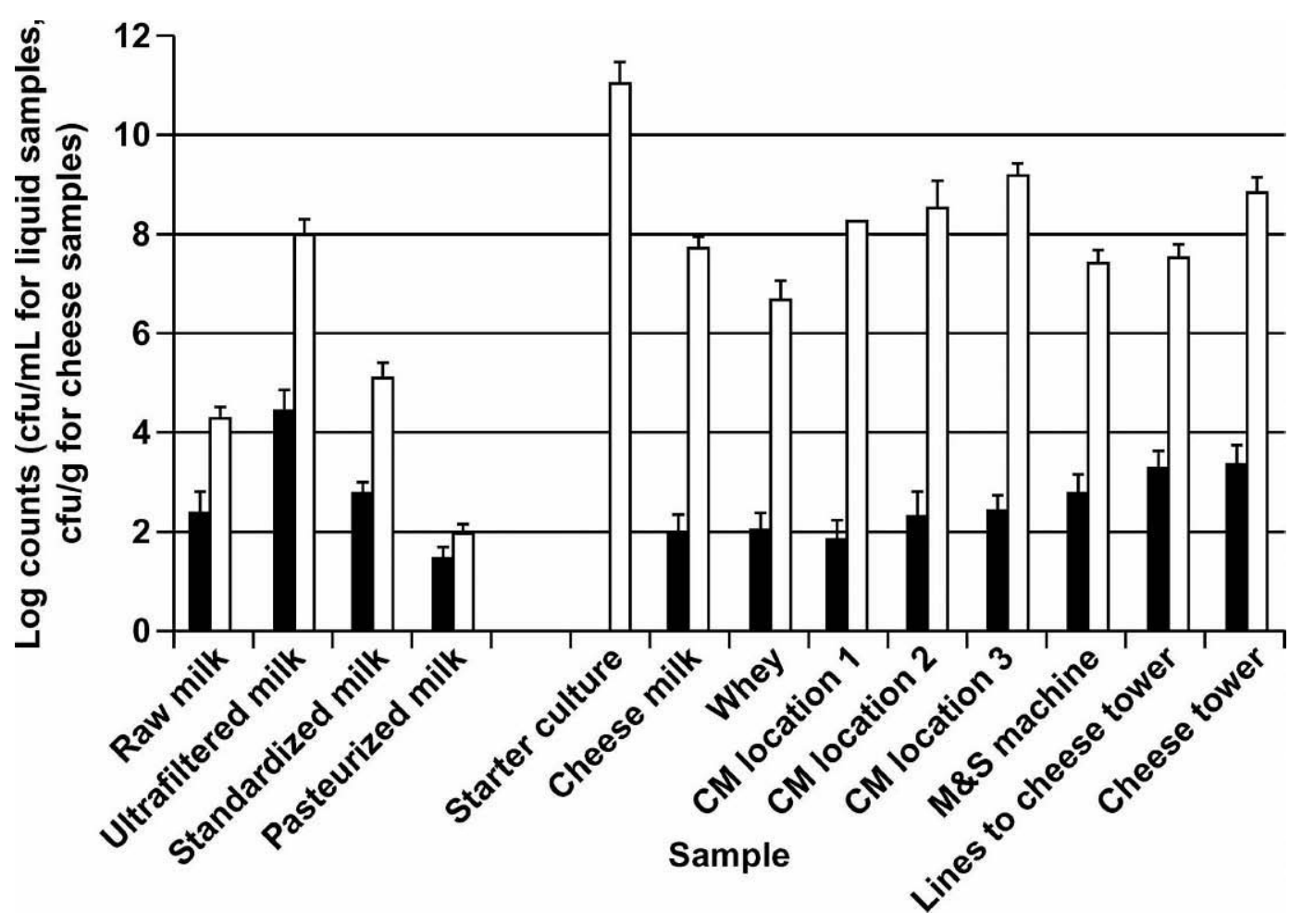

Figure 3. Anaerobic plate counts $(\square)$ and aerobic counts $(\square)$ from samples of milk, ingredients, cheese curd, and equipment surfaces during cheese manufacture in a commercial cheese plant (mean of 3 cheese vats followed throughout processing). $\mathrm{CM}=\mathrm{Cheddarmaster;}$ $\mathrm{M} \& \mathrm{~S}=$ milling and salting.

Figures 6 and 7 present the growth of NSLAB in cheese during aging compared with starter bacteria. The NSLAB population in cheeses contaminated with $L b$. curvatus increased quickly during cheese manufacture and remained high throughout $168 \mathrm{~d}$ of aging. This finding shows that $L b$. curvatus can not only survive in cheese but also grow rapidly in cheese during manufacture and aging.

Even slight contamination (initial count of 2 to 2.5 $\log \mathrm{cfu} / \mathrm{mL}$ in pilot plant experiments) of cheese milk with $L b$. curvatus and $P$. acidilactici can result in high NSLAB counts in cheeses in as few as $7 \mathrm{~d}$. Large $L b$. curvatus and $P$. acidilactici populations in cheese is of major concern because, over time, these NSLAB result in CLC in cheese (Somers et al., 2001; Chou et al., 2003).

Lactose, L(+)-/D(-)-Lactic Acid. Lactose concentration in 1-d-old cheese has been reported to be in the range of 0.7 to $1.5 \%$ (Fox et al., 2000). In the present study, the lactose to protein ratio in UF cheese milk was 1.23 and for standard milk was 1.47 . It was hypothesized that decreasing the lactose concentration in the cheese milk in proportion to protein would lead to lower residual lactose concentration in the cheese curd and less likelihood of occurrence of CLC. Turner and Thomas (1980) demonstrated that if the residual lactose concentration in cheese curd is high, higher concentrations of heterofermentative products might be produced in the cheese by NSLAB. In the present study, mean lactose concentration in cheese made with standard milk was $0.41 \%$ compared with $0.39 \%$ in UF milk cheeses on the first day after cheese manufacture (Table 1). No significant differences were observed in the lactose concentration between UF and standard cheeses throughout ripening, whether inoculated with NSLAB or not.

Within $14 \mathrm{~d}$, the concentration of lactose was 0.03 to $0.10 \%$ in both UF and standard cheeses. These results suggest that during initial days of aging, starter bacteria were active and converted most of the residual lactose in the cheese curd to L(+)-lactic acid (Table 1). The results are consistent with those of Huffman and Kristoffersen (1984) wherein a lactose concentration of $4.8 \%$ in cheese milk was used. Lactose concentration in 30 - and 180-d-old Cheddar cheese was reported to be 0.07 and $0.01 \%$, respectively (Huffman and Kristoffersen, 1984). Mean lactose concentration measured in experimental cheeses manufactured in this study was 0.03 to $0.10 \%$ at $d 28$ and 0.02 to $0.08 \%$ at $d 168$.

Total lactic acid concentration in experimental cheeses after $14 \mathrm{~d}$ was 0.7 to $1.4 \%$, which was close to 
a)

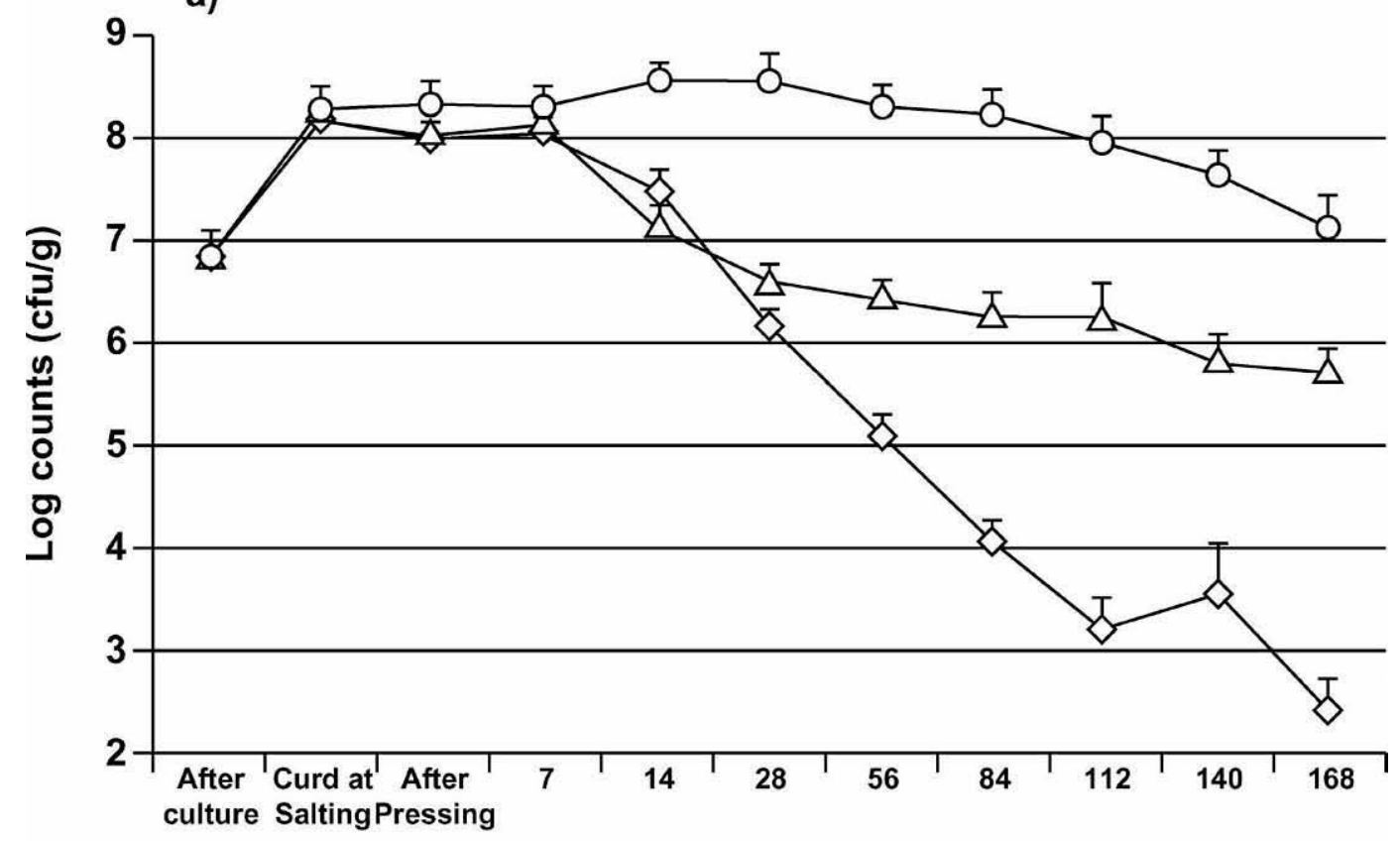

Storage (d)

b)

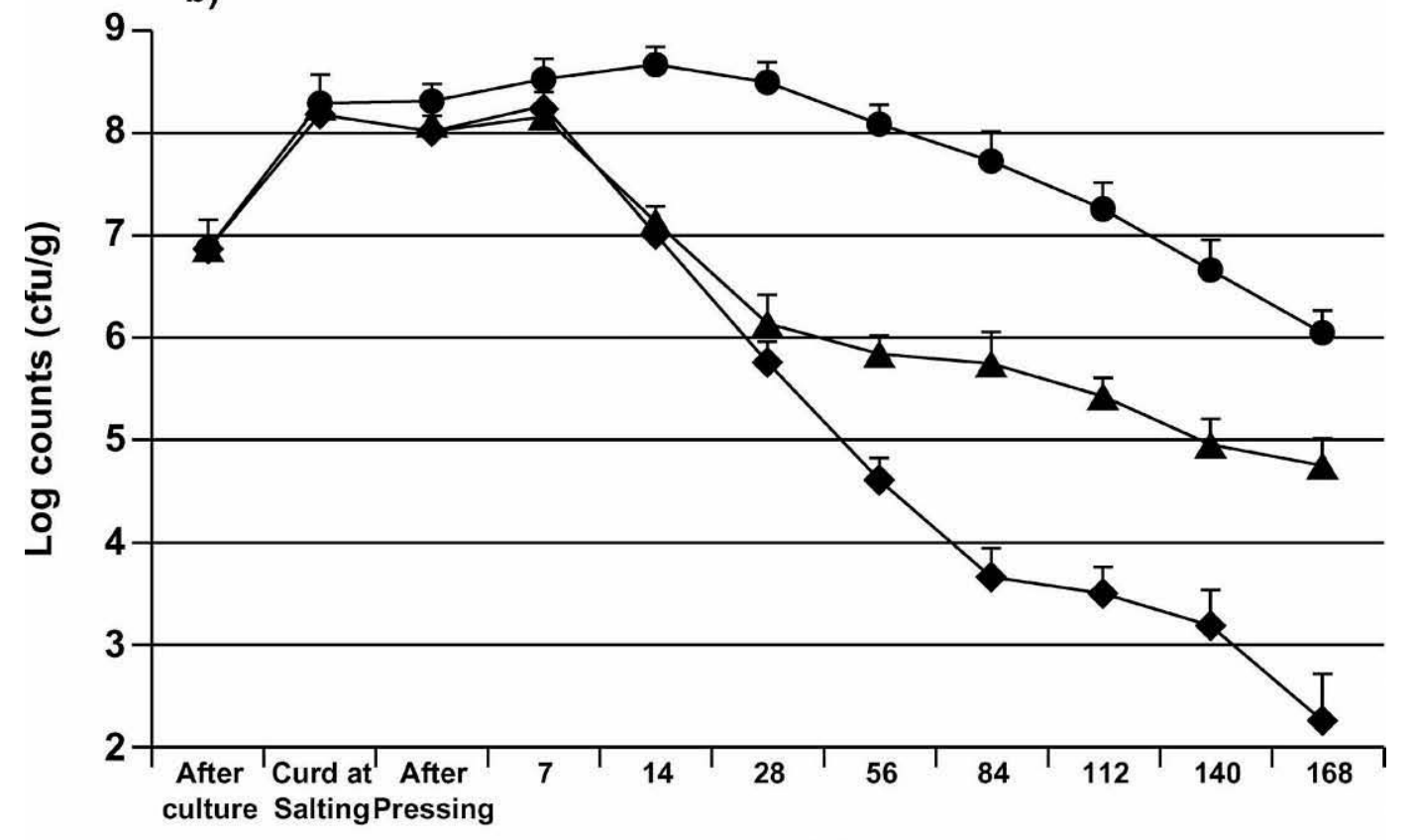

Storage (d)

Figure 4. Total aerobic plate counts (LM17 agar) in standard cheese with $(\bigcirc, \bigcirc$ with Lactobacillus curvatus; $\triangle, \mathbf{\Delta}$ with Pediococcus acidilactici) and without $(\diamond, \diamond)$ adjuncts; average of 2 replicates aged at a) $7.2^{\circ} \mathrm{C}$, and b) $10^{\circ} \mathrm{C}$.

the $1.5 \%$ lactic acid reported in 14-d-old Cheddar cheese (Fox et al., 2000). The concentration of total lactic acid in standard and UF cheeses were similar (Table 2), suggesting that the production of total lactic acid in cheeses was not affected by the addition of adjunct cultures or lactose:protein ratio. After $14 \mathrm{~d}$ of aging, $\mathrm{L}(+)-$ lactic acid reached the concentration of 0.8 to $1.4 \%$ in UF cheeses and 0.6 to $1.4 \%$ in standard cheeses (Table 
a)

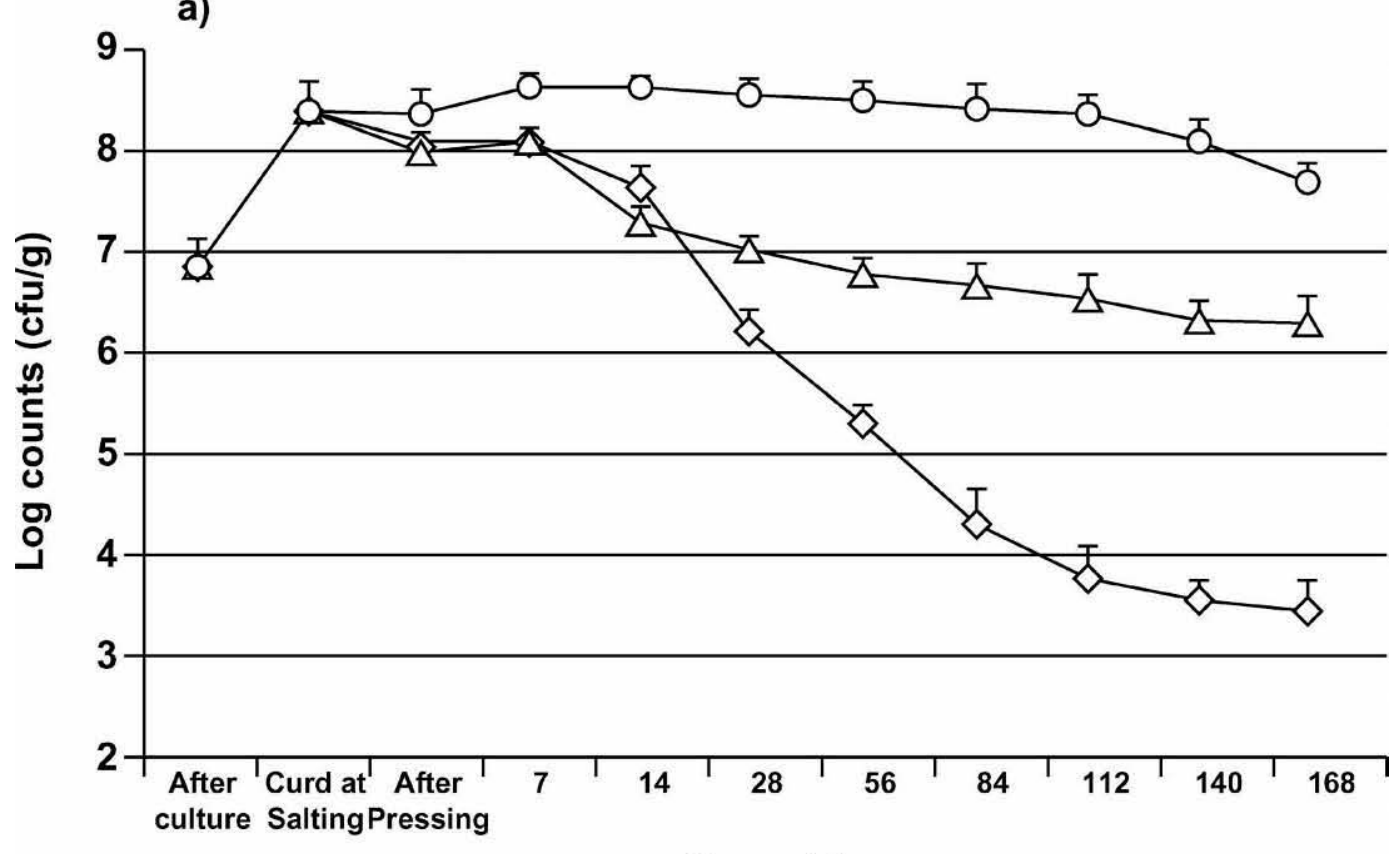

Storage (d)

b)

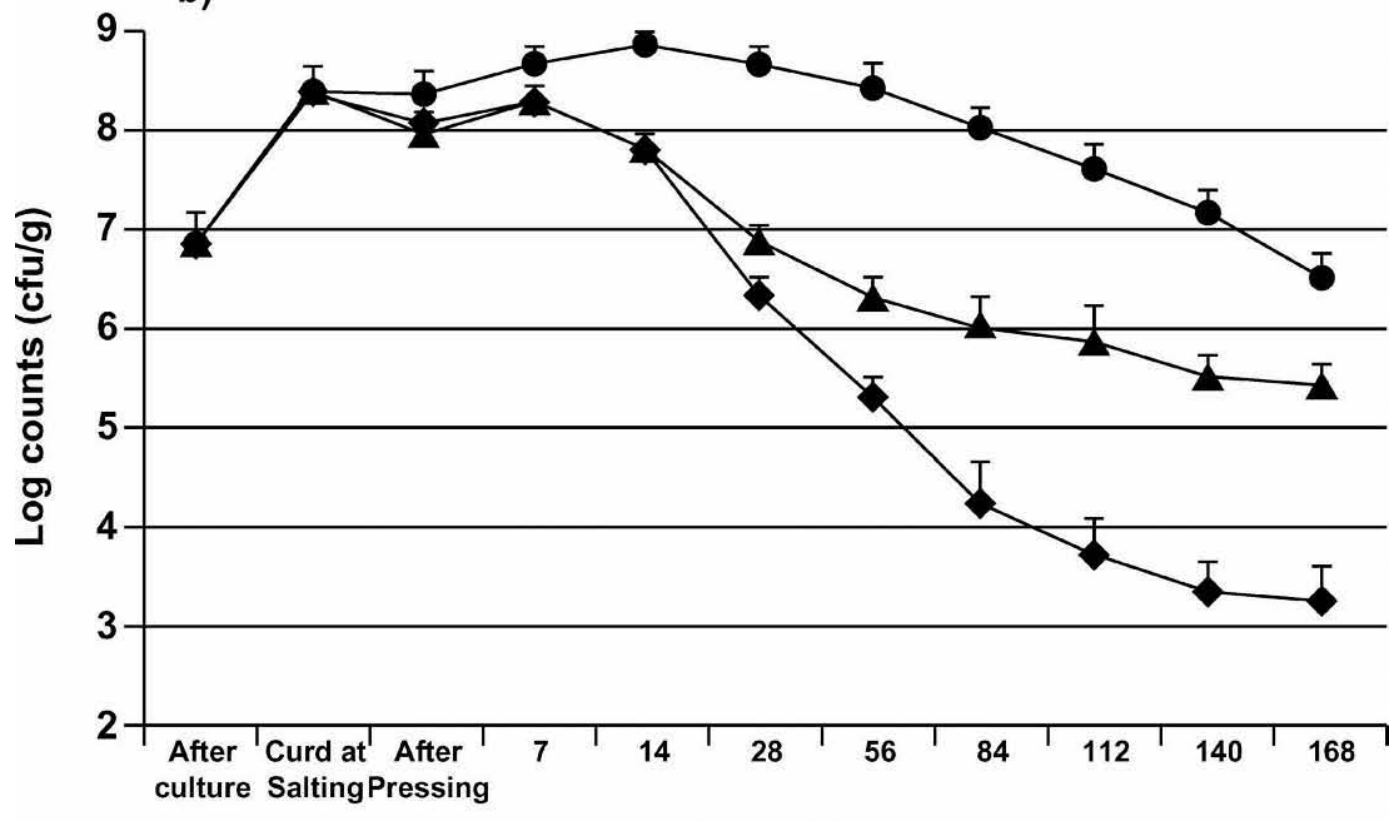

Storage (d)

Figure 5. Total aerobic plate counts (LM17 agar) in UF cheese with $(\bigcirc, \bigcirc$ with Lactobacillus curvatus; $\triangle, \mathbf{\Delta}$ with Pediococcus acidilactici) and without $(\diamond, \diamond)$ adjuncts; average of 2 replicates aged at a) $7.2^{\circ} \mathrm{C}$, and b) $10^{\circ} \mathrm{C}$.

2). Following this increase, $\mathrm{L}(+)$-lactic acid concentration declined and remained between 0.5 and $1.0 \%$ in UF cheese and between 0.4 and $0.9 \%$ in standard cheeses. The decrease in $\mathrm{L}(+)$-lactic acid in cheeses was likely due to racemization of some of $\mathrm{L}(+)$-lactic acid to $\mathrm{D}(-)$-lactic acid or fermentation of $\mathrm{L}(+)$-lactic acid to acetate or other end products. L(+)-Lactic acid concentrations on $\mathrm{d} 1$ in cheeses made with added $L b$. curvatus 
a)

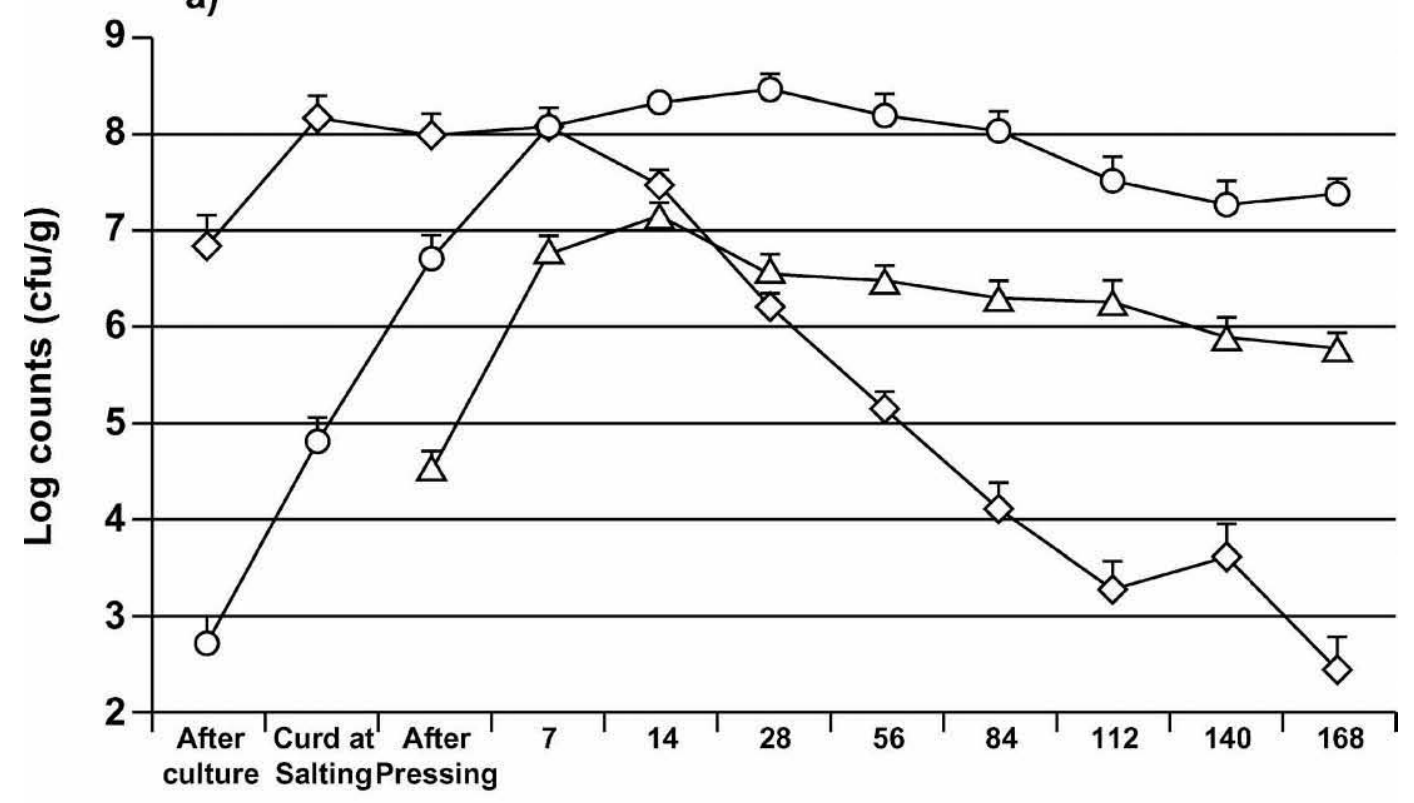

Storage (d)

b)

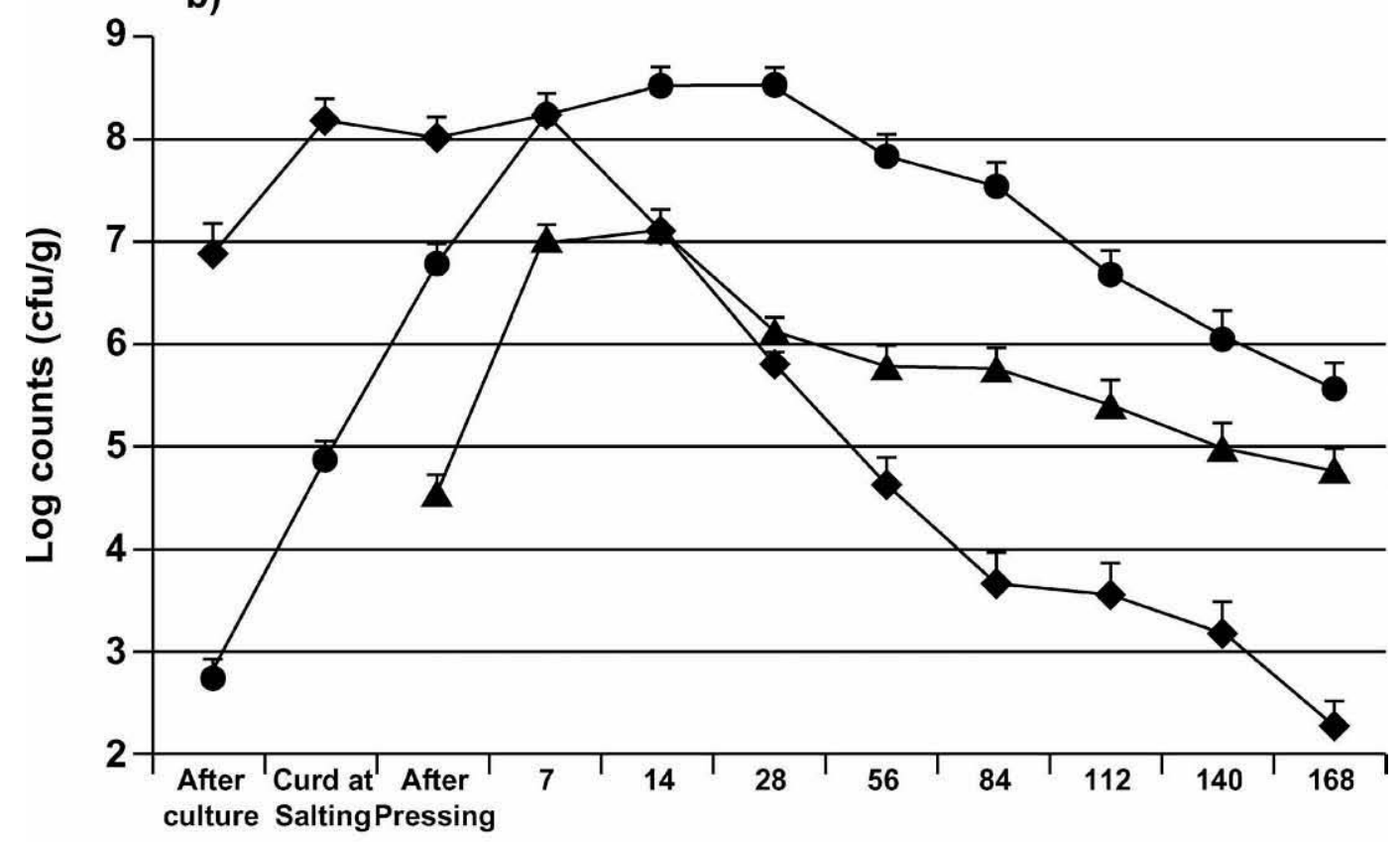

Storage (d)

Figure 6. Total aerobic plate counts (LM17 agar) in standard cheese $(\diamond, \diamond$; control) and nonstarter lactic acid bacteria counts in standard cheese with Lactobacillus curvatus $(\bigcirc, \bullet)$ or Pediococcus acidilactici $(\triangle, \mathbf{\Delta})$. Lactobacillus curvatus was enumerated on Rogosa SL agar under anaerobic conditions, and P. acidilactici was enumerated on LM17 agar with 4\% salt under aerobic conditions; average of 2 replicates aged at a) $7.2^{\circ} \mathrm{C}$, and b) $10^{\circ} \mathrm{C}$.

were 1.13 to $1.26 \%$, compared with 0.80 to $0.82 \%$ in cheeses with $P$. acidilactici, and 0.75 to $0.85 \%$ in control cheeses. $\mathrm{L}(+)$-Lactic acid concentrations were found to be statistically insignificant across the experimental batches, showing no effect of ultrafiltration or presence of NSLAB on amount of $\mathrm{L}(+)$-lactic acid. 
a)

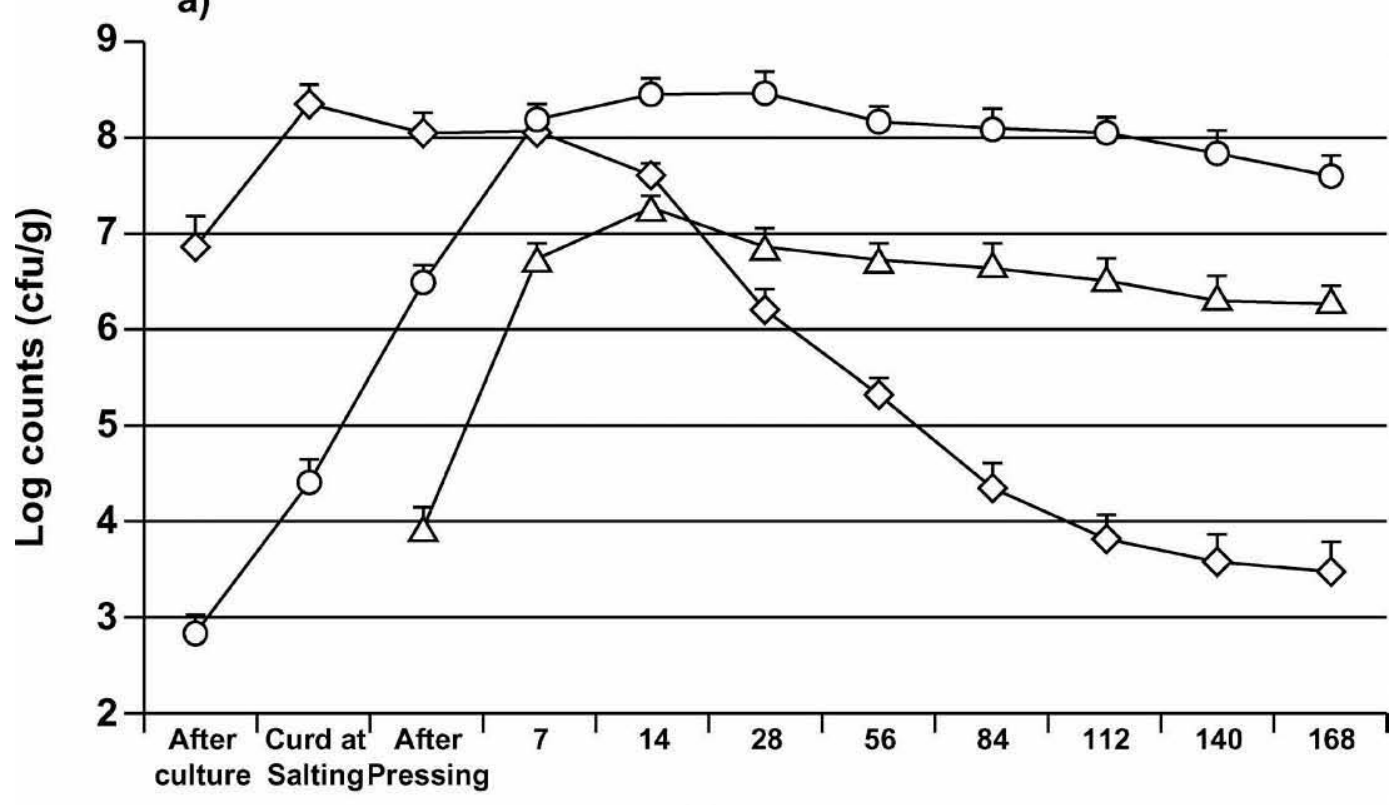

Storage (d)

b)

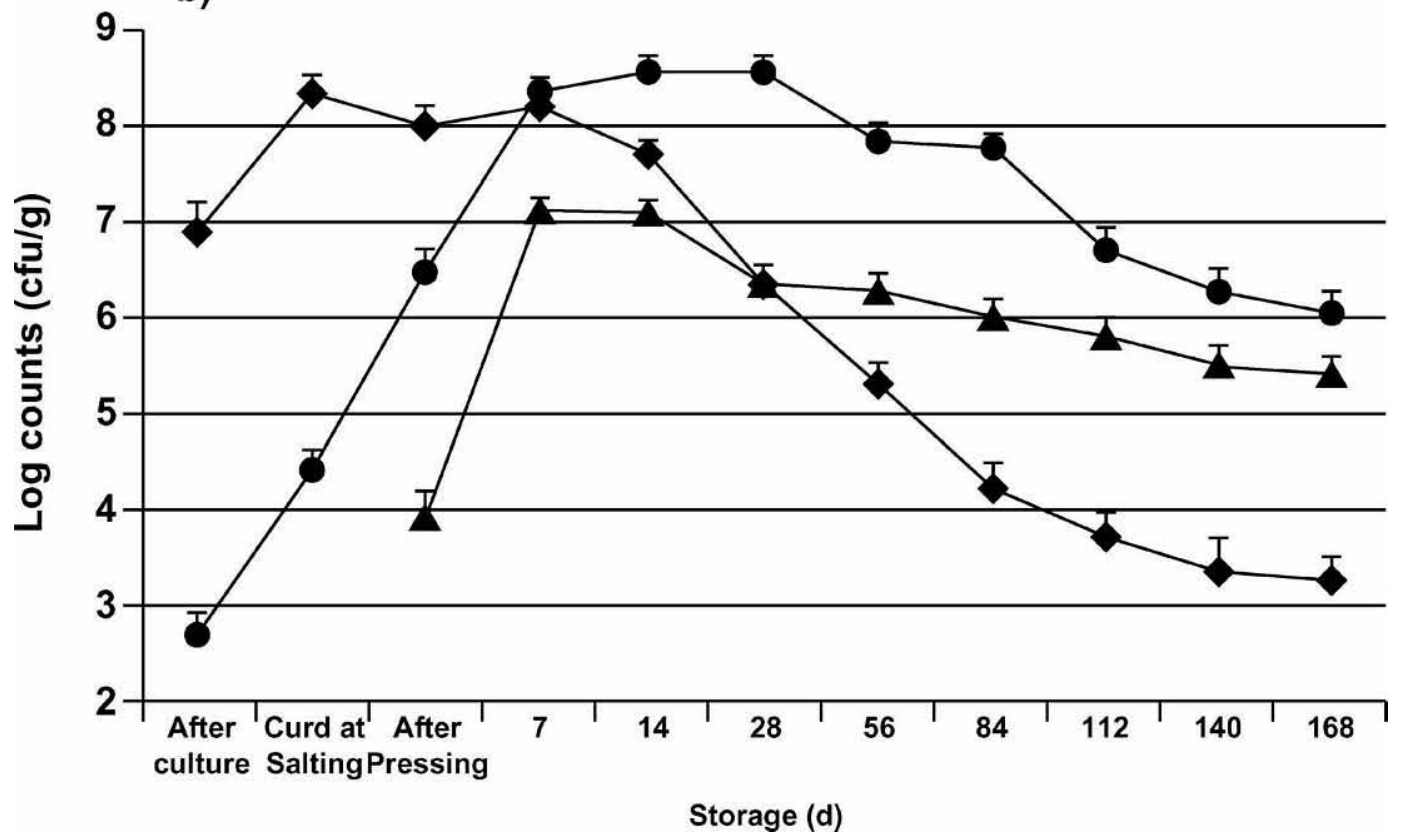

Figure 7. Total aerobic plate counts (enumerated on LM17 agar under aerobic conditions) in UF cheese ( $\diamond$, $;$ control) and nonstarter lactic acid bacteria counts in standard cheese with Lactobacillus curvatus $(\bigcirc, \bigcirc)$ or Pediococcus acidilactici $(\triangle, \mathbf{\Delta})$. Lactobacillus curvatus was enumerated on Rogosa SL agar under anaerobic conditions, and P. acidilactici was enumerated on LM17 agar with $4 \%$ salt under aerobic conditions; average of 2 replicates aged at a) $7.2^{\circ} \mathrm{C}$, and b) $10^{\circ} \mathrm{C}$.

The $\mathrm{D}(-)$-lactic acid in Cheddar cheese typically arises either from fermentation of lactose or by racemization of $\mathrm{L}(+)$-lactic acid by NSLAB. The initial form of lactic acid in all cheeses was L(+)-lactic acid only, regardless of addition of adjunct culture. A significant $(P<0.05)$ increase in $\mathrm{D}(-)$-lactic acid concentration $(0.45$ to $0.60 \%)$ 
Table 1. Lactose concentration ( $\mathrm{g} / 100 \mathrm{~g}$ of cheese) in experimental Cheddar cheese during $168 \mathrm{~d}$ of aging ${ }^{1}$

\begin{tabular}{|c|c|c|c|c|c|c|c|c|c|c|}
\hline Treatments & $\begin{array}{l}\text { Aging } \\
\text { temperature } \\
\left({ }^{\circ} \mathrm{C}\right)\end{array}$ & \multicolumn{9}{|c|}{ Time (d) } \\
\hline Standard cheese +0 adjunct & 7.2 & $0.443^{\mathrm{ac}}$ & $0.139^{\mathrm{ac}}$ & $0.069^{\mathrm{ac}}$ & $0.060^{\mathrm{ac}}$ & $0.030^{\mathrm{ac}}$ & $0.030^{\mathrm{ac}}$ & $0.030^{\mathrm{ac}}$ & $0.028^{\mathrm{ac}}$ & $0.021^{\mathrm{ac}}$ \\
\hline \multirow[t]{2}{*}{ UF cheese +0 adjunct } & 7.2 & $0.408^{\mathrm{ad}}$ & $0.188^{\text {ad }}$ & $0.046^{\text {ad }}$ & $0.028^{\text {ad }}$ & $0.036^{\text {ad }}$ & $0.027^{\text {ad }}$ & $0.061^{\text {ad }}$ & $0.039^{\text {ad }}$ & $0.035^{\mathrm{ad}}$ \\
\hline & 10 & $0.408^{\mathrm{bc}}$ & $0.105^{\mathrm{bc}}$ & $0.078^{\mathrm{bc}}$ & $0.030^{\mathrm{bc}}$ & $0.063^{b c}$ & $0.063^{b c}$ & $0.072^{\mathrm{bc}}$ & $0.061^{\mathrm{bc}}$ & $0.059^{\mathrm{bc}}$ \\
\hline \multirow{2}{*}{$\begin{array}{l}\text { Standard cheese }+1 \text { adjunct } \\
(P . \text { acidilactici })\end{array}$} & 7.2 & $0.405^{\mathrm{ac}}$ & $0.095^{\mathrm{ac}}$ & $0.082^{\mathrm{ac}}$ & $0.076^{\mathrm{ac}}$ & $0.071^{\text {ac }}$ & $0.070^{\mathrm{ac}}$ & $0.070^{\mathrm{ac}}$ & $0.059^{\mathrm{ac}}$ & $0.050^{\mathrm{ac}}$ \\
\hline & 10 & $0.405^{\mathrm{bd}}$ & $0.071^{\mathrm{bd}}$ & $0.060^{\mathrm{bd}}$ & $0.055^{\mathrm{bd}}$ & $0.045^{\mathrm{bd}}$ & $0.040^{\mathrm{bd}}$ & $0.041^{\mathrm{bd}}$ & $0.040^{\mathrm{bd}}$ & $0.038^{\mathrm{bd}}$ \\
\hline \multirow{2}{*}{$\begin{array}{l}\text { Standard cheese }+1 \text { adjunct } \\
\text { (Lb. curvatus })\end{array}$} & 7.2 & $0.359^{\text {ad }}$ & $0.072^{\mathrm{ad}}$ & $0.069^{\text {ad }}$ & $0.051^{\mathrm{ad}}$ & $0.051^{\text {ad }}$ & $0.049^{\text {ad }}$ & $0.053^{\mathrm{ad}}$ & $0.051^{\mathrm{ad}}$ & $0.045^{\mathrm{ad}}$ \\
\hline & 10 & $0.359^{\mathrm{bc}}$ & $0.036^{\mathrm{bc}}$ & $0.033^{\text {bc }}$ & $0.028^{\mathrm{bc}}$ & $0.030^{\mathrm{bc}}$ & $0.025^{\mathrm{bc}}$ & $0.021^{\mathrm{bc}}$ & $0.020^{\mathrm{bc}}$ & $0.020^{\mathrm{bc}}$ \\
\hline \multirow{2}{*}{$\begin{array}{l}\mathrm{UF} \text { cheese }+1 \text { adjunct } \\
(\text { Lb. curvatus })\end{array}$} & 7.2 & $0.472^{\mathrm{ab}}$ & $0.149^{\mathrm{ab}}$ & $0.051^{\mathrm{ab}}$ & $0.051^{\mathrm{ab}}$ & $0.049^{\mathrm{ab}}$ & $0.052^{\mathrm{ab}}$ & $0.063^{\mathrm{ab}}$ & $0.061^{\mathrm{ab}}$ & $0.059^{\mathrm{ab}}$ \\
\hline & 10 & $0.472^{\mathrm{cd}}$ & $0.108^{\mathrm{cd}}$ & $0.030^{\mathrm{cd}}$ & $0.025^{\mathrm{cd}}$ & $0.029^{c d}$ & $0.031^{\mathrm{cd}}$ & $0.032^{\mathrm{cd}}$ & $0.031^{\mathrm{cd}}$ & $0.032^{\text {cd }}$ \\
\hline
\end{tabular}

${ }^{\mathrm{a}-\mathrm{d}}$ Means within the same category (cheese with same adjunct microorganisms and at a particular aging time) with different superscripts differ $(P<0.05)$.

${ }^{1}$ All values are the mean of 3 replicates.

was observed in cheeses with $L b$. curvatus after $168 \mathrm{~d}$ of aging, with a corresponding decrease in concentration of $\mathrm{L}(+)$-lactic acid, indicating racemization. No significant increase in $\mathrm{D}(-)$-lactic acid was observed in control cheeses or cheeses inoculated with $P$. acidilactici as adjunct. No significant differences were observed in concentration of $\mathrm{D}(-)$-lactic acid in UF cheeses and standard cheeses.
Aging Temperature. It was hypothesized that the NSLAB population would be higher in cheeses aged at $10^{\circ} \mathrm{C}$ than in cheeses aged at $7.2^{\circ} \mathrm{C}$. High aging temperatures $\left(10\right.$ to $\left.13^{\circ} \mathrm{C}\right)$ favor the growth of NSLAB, leading to higher microbial populations in cheese during aging. The effect of temperature on the microbial population was significant. In early aging, counts in both standard and UF cheeses were higher at $10^{\circ} \mathrm{C}$ than at $7.2^{\circ} \mathrm{C}$.

Table 2. $\mathrm{L}(+)$ - and $\mathrm{D}(-)$-lactic acid concentration ( $\mathrm{g} / 100 \mathrm{~g}$ of cheese) in experimental Cheddar cheeses ${ }^{1}$

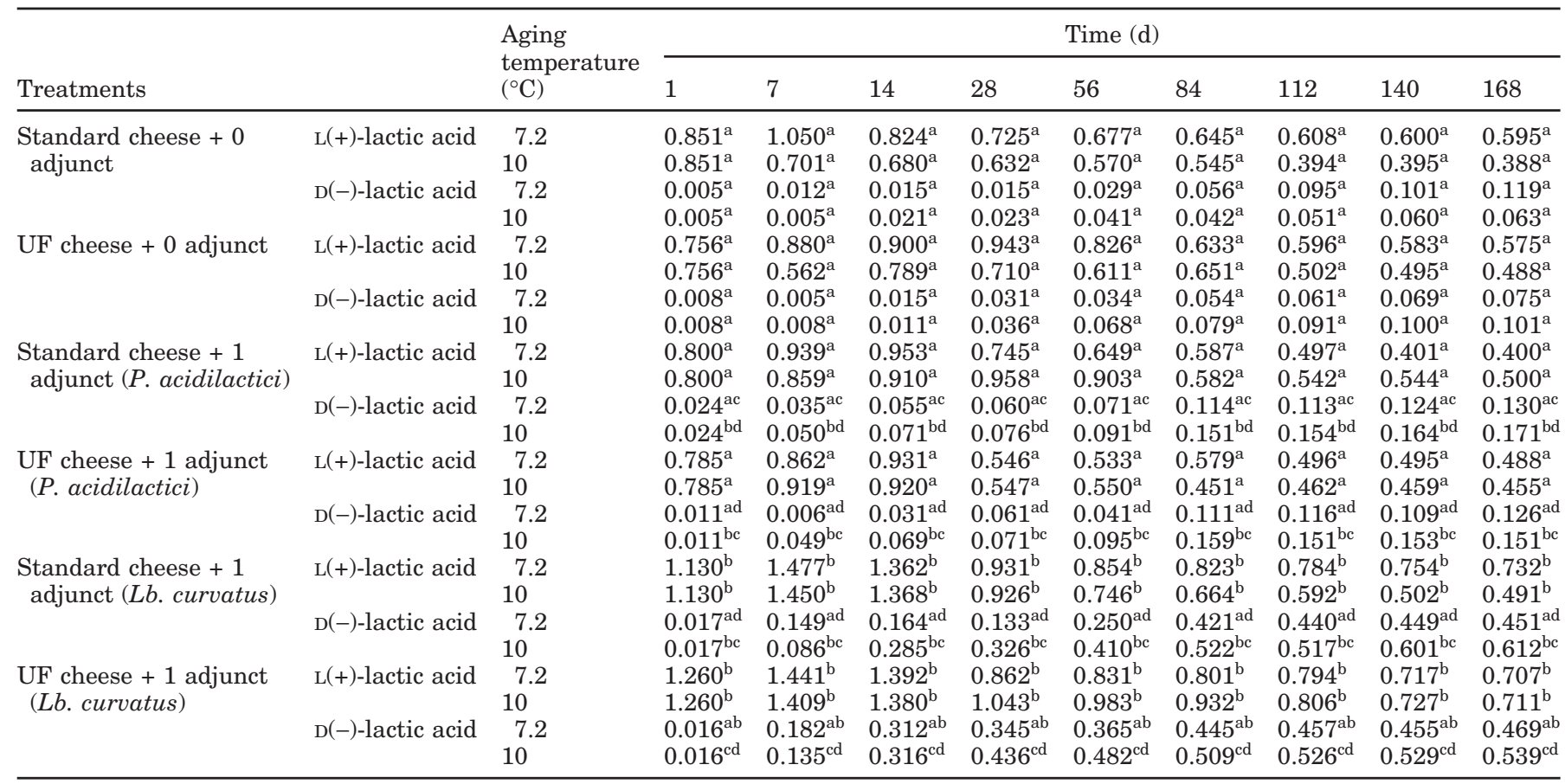

${ }^{\mathrm{a}-\mathrm{d}}$ Means within the same category (cheese with same adjunct microorganisms, $\mathrm{L}(+)$-lactic acid, $\mathrm{D}(-)$-lactic acid, at particular aging time) with different superscripts differ $(P<0.05)$.

${ }^{1}$ All values are the mean of 3 replicates. 
However, after $168 \mathrm{~d}$ of aging, total microbial counts were lower at the higher temperature (Figures 4 and 5). During the first $14 \mathrm{~d}$ of aging there were significant differences in lactose concentration in cheeses stored at $10^{\circ} \mathrm{C}$ than at $7.2^{\circ} \mathrm{C}$. Presence of lower concentration of lactose and higher concentration of lactic acid in cheeses at $10^{\circ} \mathrm{C}$ compared with $7.2^{\circ} \mathrm{C}$ suggest higher metabolic activity in cheeses stored at higher temperatures. Cheeses stored at $10^{\circ} \mathrm{C}$ with added NSLAB produced significantly $(P<0.05)$ higher concentrations of $\mathrm{D}(-)$-lactic acid than cheeses stored at $7.2^{\circ} \mathrm{C}$. This finding is supported by Scott (1998), who observed that high aging temperatures accelerated both bacterial growth and biochemical reactions. At d 14, cheeses inoculated with $P$. acidilactici were observed to contain significantly $(P<0.05)$ higher total counts when aged at $10^{\circ} \mathrm{C}$ than in cheeses aged at $7.2^{\circ} \mathrm{C}$. Similarly, the NSLAB counts in cheeses inoculated with $L b$. curvatus were significantly $(P<0.05)$ higher in cheeses aged at $10^{\circ} \mathrm{C}$ than in cheeses aged at $7.2^{\circ} \mathrm{C}$ at $\mathrm{d} 14$ (Figures 6 and 7). The higher total and NSLAB counts confirm that both starter and NSLAB in these cheeses multiply faster at $10^{\circ} \mathrm{C}$ than at $7.2^{\circ} \mathrm{C}$.

In cheeses aged for $168 \mathrm{~d}$, the total bacteria and NSLAB counts inoculated with $L b$. curvatus were significantly $(P<0.05)$ lower at $10^{\circ} \mathrm{C}$ than at $7.2^{\circ} \mathrm{C}$. Similarly, in cheeses inoculated with $P$. acidilactici, NSLAB had significantly lower counts $(P<0.05)$ in cheeses aged at $10^{\circ} \mathrm{C}$ than in cheeses aged at $7.2^{\circ} \mathrm{C}$ after $168 \mathrm{~d}$ (Figures 6 and 7). Microorganisms metabolized available carbohydrate sources at increased rates during aging of cheeses at high temperatures, resulting in higher total microbial counts in cheeses aged at $10^{\circ} \mathrm{C}$ compared with cheeses aged at $7.2^{\circ} \mathrm{C}$ in the first 14 $\mathrm{d}$ of aging. However, as the available energy sources became depleted, the microorganisms in cheeses aged at $10^{\circ} \mathrm{C}$ may have died earlier than the microorganisms in cheeses aged at $7.2^{\circ} \mathrm{C}$, resulting in lower counts after $168 \mathrm{~d}$.

\section{Formation of CLC}

Use of Adjunct Cultures. In the cheese trials conducted under controlled conditions at the WSU Creamery, CLC were observed on the cheeses inoculated with $L b$. curvatus, but not on cheeses inoculated with $P$. acidilactici or on control cheeses, although low $\mathrm{pH}$ values were observed in all cheeses after $168 \mathrm{~d}$ aging (Table $3)$. Discoloration and sweating of cheeses were observed but absence of CLC in control cheeses was different from the results obtained by Swearingen et al. (2004b). This may be due to differences in packaging; all our experimental cheeses were vacuum packaged in highbarrier packages with little loss of moisture. Calcium lactate crystals were observed in control cheeses that were gas flushed (Agarwal et al., 2005). The cheese trials showed that growth of any racemizing NSLAB does not always result in CLC development in cheese, although select species may yield development of CLC. Although no CLC were observed in experimental cheeses inoculated with $P$. acidilactici, the potential threat of CLC by other Pediococcus spp. and Lactobacillus spp. cannot be ruled out, because both bacteria not only survive in $4 \%$ salt to moisture ratio but also grow at typical aging temperatures (Thomas and Crow, 1983). Microorganisms of Pediococcus spp. and Lactobacillus spp. continue to ferment lactose to lactic acid after pressing and cooling of cheese blocks, leading to increased concentrations of $\mathrm{D}(-)-/ \mathrm{L}(+)$-lactate.

The population of inoculated $L b$. curvatus increased rapidly during cheese manufacturing and remained above $6.0 \mathrm{log} \mathrm{cfu} / \mathrm{g}$ throughout the ripening period, demonstrating that contamination of cheese milk or curd with $L b$. curvatus during cheese making will lead to a rapid increase in population of $L b$. curvatus. Lactobacillus curvatus can become a dominant microflora in cheese. Due to its racemizing ability, Lb. curvatus is of concern to cheese manufacturers. Calcium lactate crystals may result in cheeses contaminated with a small population (as low as $2.5 \log \mathrm{cfu} / \mathrm{mL}$ in cheese milk) of Lb. curvatus microorganisms. Lactobacillus curvatus are of particular concern because $L b$. curvatus biofilms are difficult to remove from cheese-making equipment and survive traditional cleaning and sanitization regimens in dairy plants (Somers et al., 2001). The need for a strict program of cleaning and sanitation to remove biofilms in cheese manufacturing plants is recommended.

Milk Composition. It was hypothesized that CLC would form in cheese inoculated with NSLAB made from standard milk but not from UF milk. Because cheeses made with standard milk contain higher lactose to protein ratio, increased growth of NSLAB, increased racemization of $\mathrm{L}(+)$-lactate to $\mathrm{D}(-)$-lactate, and increased development of CLC were expected. This hypothesis was not supported by the current research because 1) no crystals were observed in cheeses without Lb. curvatus, regardless of lactose:protein ratio, and 2) crystals were observed in both standard and UF cheeses inoculated with $L b$. curvatus at the same time and same intensity. Although 19\% of the lactose was removed by UF in cheese milk to reduce the lactose:protein ratio, the lactose contents in 1-d-old UF cheeses aged at $7.2^{\circ} \mathrm{C}$ were not different than the lactose content in standard cheeses (Table 1). Changing the lactose:protein ratio in cheese milk did not reduce the formation of CLC.

Aging Temperature. Upon opening the vacuumpackaged cheeses inoculated with $L b$. curvatus, CLC 
Table 3. Proximate analysis of experimental Cheddar cheeses at d 2 compared with typical Cheddar cheese ${ }^{1}$

\begin{tabular}{|c|c|c|c|c|c|c|c|}
\hline Treatments & $\begin{array}{l}\text { Fat }^{2} \\
(\%, \text { wet } \\
\text { weight } \\
\text { basis })\end{array}$ & $\begin{array}{l}\text { Protein }^{2} \\
\text { (\%, wet } \\
\text { weight } \\
\text { basis) }\end{array}$ & $\begin{array}{l}\text { Moisture }^{2} \\
(\%, \text { wet } \\
\text { weight } \\
\text { basis })\end{array}$ & $\begin{array}{l}\text { Salt }^{2} \\
\text { (\%, wet } \\
\text { weight } \\
\text { basis })\end{array}$ & $\begin{array}{l}\mathrm{S} / \mathrm{M}^{2,3} \\
(\%, \text { wet } \\
\text { weight } \\
\text { basis })\end{array}$ & $\mathrm{pH}^{4}$ & $\begin{array}{l}\text { Lactose }^{5} \\
\text { (g/100 g } \\
\text { of cheese) }\end{array}$ \\
\hline Standard cheese +1 adjunct $(P$. acidilactici) & $34.0^{\mathrm{a}}$ & $24.5^{\mathrm{a}}$ & $35.7^{\mathrm{a}}$ & $1.62^{\mathrm{a}}$ & $4.54^{\mathrm{a}}$ & $4.85^{\mathrm{a}}$ & $0.41^{\mathrm{a}}$ \\
\hline Standard cheese +1 adjunct ( $L b$. curvatus) & $33.8^{\mathrm{a}}$ & $24.6^{\mathrm{a}}$ & $36.2^{\mathrm{ab}}$ & $1.22^{\mathrm{b}}$ & $3.36^{\mathrm{b}}$ & $5.03^{\mathrm{ab}}$ & $0.36^{\mathrm{ab}}$ \\
\hline UF cheese +0 adjunct & $34.0^{\mathrm{a}}$ & $25.5^{\mathrm{b}}$ & $36.4^{\mathrm{ab}}$ & $1.61^{\mathrm{a}}$ & $4.44^{\mathrm{a}}$ & $4.99^{\mathrm{a}}$ & $0.41^{\mathrm{a}}$ \\
\hline
\end{tabular}

${ }^{\mathrm{a}, \mathrm{b}}$ Means within a column with different superscripts differ $(P<0.05)$.

${ }^{1}$ Typical Cheddar cheese according to Kosikowski and Mistry (1997).

${ }^{2}$ Analyzed on $\mathrm{d} 2$ after cheese manufacture.

${ }^{3}$ Salt in moisture.

${ }^{4}$ Analyzed on $\mathrm{d} 1$ after cheese manufacture.

${ }^{5}$ Analyzed 6 mo after cheese manufacture.

were observed on all surfaces after $56 \mathrm{~d}$ of aging. Crystals were observed throughout the cheese matrix after $112 \mathrm{~d}$ of aging, regardless of storage temperature. The diffraction patterns of the crystals isolated from experimental cheeses inoculated with $L b$. curvatus were equivalent to the diffraction patterns of calcium lactate pentahydrate crystals, confirming the presence of CLC. After $84 \mathrm{~d}$ of aging, the size and intensity of the CLC crystals on cheese with $L b$. curvatus increased enough so that they were visible before opening, regardless of temperature. After $112 \mathrm{~d}$ of aging, the entire Cheddar cheese surface was covered with very small crystals. The crystals were obvious before opening cheeses with Lb. curvatus after $140 \mathrm{~d}$ of aging, regardless of storage temperature. The size of the crystals increased throughout the 168-d aging period, regardless of storage temperature. Although translucent crystals were observed on control cheeses or cheeses inoculated with P. acidilactici after $84 \mathrm{~d}$ of aging, the crystals were not identified as CLC.

\section{CONCLUSIONS}

Although not all NSLAB are able to racemize enough $\mathrm{L}(+)$-lactate to $\mathrm{D}(-)$-lactate to cause CLC in cheese, contamination of cheese with certain racemase-positive strains of NSLAB can cause CLC in cheese. Racemasepositive Lactobacilli spp. have been responsible for formation of CLC in cheeses (Johnson et al., 1990b; Somers et al., 2001; Chou et al., 2003). Higher counts of NSLAB were observed at $10^{\circ} \mathrm{C}$ compared with $7.2^{\circ} \mathrm{C}$ during the first $14 \mathrm{~d}$ of aging; however, with extended aging up to $168 \mathrm{~d}$, lower NSLAB counts were observed at higher temperatures than at lower temperatures. Calcium lactate crystals were observed on cheeses inoculated with $L b$. curvatus after $56 \mathrm{~d}$, showing that $L b$. curvatus can be a problem in cheese plants because it is able to racemize $\mathrm{L}(+)$-lactate to $\mathrm{D}(-)$-lactate. The increased NSLAB population, coupled with the fact that crystals appeared on both standard and UF milk cheeses containing $L b$. curvatus, shows that reducing the lactose:protein ratio does not necessarily inhibit CLC formation. Instead, cheese processing plants must endeavor to remove biofilms of lactate racemase-positive NSLAB through strict cleaning and sanitization regimens.

\section{ACKNOWLEDGMENTS}

Appreciation is extended to the Washington State University Creamery management, Russ Salvadalena, Nial Yager, and John Haugen, for use of the pilot plant facilities. Gratitude is also extended to Lloyd Luedecke, John Haugen, and Reyad Shaker for their immense help during collection of samples from the cheese plants. Special thanks to Reyad Shaker and Xiaoming Liu for their help in cheese making, and Marc Evans for statistical consultation. This research was funded by the Washington State Dairy Products Commission.

\section{REFERENCES}

Agarwal, S., M. Costello, and S. Clark. 2005. Gas flushed packaging contributes to calcium lactate crystals in Cheddar cheese. J. Dairy Sci. 88:3773-3783.

Blake, A. J., J. R. Powers, L. O. Luedecke, and S. Clark. 2005. Enhanced lactose cheese milk does not guarantee calcium lactate crystals in finished Cheddar cheese. J. Dairy Sci. 88:2302-2311.

Cao, X., H. J. Lee, H. S. Yun, and Y. M. Koo. 2001. Solubilities of calcium and zinc lactate in water and water-ethanol mixture. Korean J. Chem. Eng. 18:133-135.

Chou, Y. E., C. G. Edwards, L. O. Luedecke, M. P. Bates, and S. Clark. 2003. Nonstarter lactic acid bacteria and aging temperature affect calcium lactate crystallization in Cheddar cheese. J. Dairy Sci. 86:2516-2524.

Dorn, F. L., and A. C. Dahlberg. 1942. Identification of the white particles found on ripened Cheddar cheese. J. Dairy Sci. 25:31-36. 
Dybing, S. T., J. A. Wiegand, S. A. Brudvig, E. A. Huang, and R. C. Chandan. 1988. Effect of processing variables on the formation of calcium lactate crystals on Cheddar cheese. J. Dairy Sci. 71:1701-1710.

Fox, P. F., T. P. Guinee, T. M. Cogan, and P. L. H. McSweeney. 2000. Fundamentals of Cheese Science. Aspen Publishers, Inc., Gaithersburg, MD.

Harper, W. J., A. M. Swanson, and H. H. Sommer. 1953. Observations on the chemical composition of white particles in several lots of Cheddar cheese. J. Dairy Sci. 36:368-372.

Huffman, L. M., and T. Kristoffersen. 1984. Does lactose concentration affects Cheddar cheese quality? N.Z. Dairy Sci. 73:30333041.

Johnson, M. E. 2004. Calcium lactate crystals in International Cheese Technology Exposition, Madison, WI.

Johnson, M. E., B. A. Riesterer, C. Chen, B. Tricomi, and N. F. Olson. 1990a. Effect of packaging and storage conditions on calcium lactate crystallization on the surface of Cheddar cheese. J. Dairy Sci. 73:3033-3041.

Johnson, M. E., B. A. Riesterer, and N. F. Olson. 1990b. Influence on nonstarter bacteria on calcium lactate crystallization on the surface of Cheddar cheese. J. Dairy Sci. 73:1145-1149.

Khalid, N. M., and E. H. Marth. 1990. Lactobacilli-their enzymes and role in ripening and spoilage of cheese: A review. J. Dairy Sci. 73:2669-2684.

Kosikowski, F. V., and V. V. Mistry. 1997. Cheese and Fermented Milk Foods. Vol. II. Procedures and Analysis. F. V. Kosikowski and Associates, Westport, CT.

Law, B., Z. Kosking, and H. Chapman. 1979. Effect of some of the manufacturing conditions on the development of flavour in Cheddar cheese. J. Soc. Dairy Technol. 32:87-90.
Marshall, R. T., ed. 1992. Standard Methods for the Examination of Dairy Products. 15th ed. Washington, DC.

McDowall, F. H., and A. K. R. McDowell. 1939. The white particles in mature Cheddar cheese. J. Dairy Res. 10:118-119.

SAS Institute. 2005. SAS User's Guide. Version 9.1. SAS Inst., Inc., Cary, NC.

Scott, R. 1998. Cheese Maturation. Chapter 15 in Cheesemaking Practice. Aspen Publishers Inc., Gaithersburg, MD.

Shakeel-Ur-Rehman, J. M. Banks, P. L. H. McSweeney, and P. F. Fox. 2000. Effect of ripening temperature on the growth and significance of non-starter lactic acid bacteria in Cheddar cheese made from raw of pasteurised milk. Int. Dairy J. 10(1/2):45-53.

Somers, E. B., M. E. Johnson, and A. C. L. Wong. 2001. Biofilm formation and contamination of cheese by nonstarter lactic acid bacteria in the dairy environment. J. Dairy Sci. 84:1926-1936.

Swearingen, P. A. 2004. Calcium lactate crystals on Cheddar cheese in International Cheese Technology Exposition, Madison, WI.

Swearingen, P. A., D. E. Adams, and T. L. Lensmire. 2004. Factors affecting calcium lactate and liquid expulsion defects in Cheddar cheese. J. Dairy Sci. 87:574-582.

Thomas, T. D., and V. L. Crow. 1983. Mechanism of D(-)-lactic acid formation in Cheddar cheese. N.Z. J. Dairy Sci. Technol. 18:131-141.

Turner, K. W., and T. D. Thomas. 1980. Lactose fermentation in Cheddar cheese and the effect of salt. N.Z. J. Dairy Sci. Technol. 15:265-276.

Van Slyke, L. L., and C. A. Publow. 1909. Pages 332-333 in The Science and Practice of Cheese-Making. Orange Judd Publ. Co., Inc., New York, NY.

Williams, A. G., S. E. Withers, and J. M. Banks. 2000. Energy sources of non-starter lactic acid bacteria isolated from Cheddar cheese. Int. Dairy J. 10(1/2):17-23. 